\title{
Strategi Komunikasi Kesehatan dalam Upaya Membangun Partisipasi Publik pada Masa Pandemi Covid-19
}

\author{
Silvia Nevane Paramasari ${ }^{1}$, Adi Nugroho ${ }^{1}$ \\ ${ }^{1}$ Magister Ilmu Komunikasi, Fakultas Ilmu Sosial dan Ilmu Politik, Universitas Diponegoro \\ Jl. Erlangga Barat 7 No. 33, Pleburan. Kecamatan Semarang Selatan, Kota Semarang, Jawa Tengah \\ E-mail: snevane.info@gmail.com
}

Received: April 2021; Accepted: Mei 2021; Published: Juni 2021

\begin{abstract}
Health communication is a systematic effort that has a positive impact on the health practice of a large population. The Covid-19 pandemic, which is felt quite suddenly, caused confusion from all sectors, one of which is the health sector. The health sector in Indonesia looks unprepared for this pandemic in communicating the Covid-19 virus to the public. Therefore, health communication, which is part of mass communication, is one of the communication models that can give information the public about health. The focus in this research is on health communication strategies during the COVID-19 pandemic. The research method used in this research is literature study. The result and conclusion of this study which is the heal th communication strategy in building public participation during the covid-19 pandemic is 1) health communication campaigns must be carried out in an integrated and sustainable manner and carried out by experts, 2) creating and implementing appropriate and effective communication strategies in handling Covid-19,3) developing appropriate, effective and efficient tactics and technical actions and procedures.
\end{abstract}

Keyword: strategic communication; Health communication; public participation; covid-19 pandemic.

\begin{abstract}
Abstrak
Komunikasi kesehatan adalah upaya sistematis yang berdampak positif pada praktik kesehatan populasi besar. Adanya pandemi covid-19 yang dirasa cukup tiba-tiba menyebabkan kebingungan dari semua sektor, salah satunya adalah sektor kesehatan. Sektor kesehatan di Indonesia terlihat belum siap dengan adanya pandemi ini dalam mengkomunikasikan virus Covid-19 kepada masyarakat. Oleh karena itu, komunikasi kesehatan yang merupakan bagian dari komunikasi massal menjadi salah satu model komunikasi yang dapat menjembatani kepada masyarakat luas tentang kesehatan Fokus dalam penelitian ini adalah strategi komunikasi kesehatan dalam masa pandemi covid-19. Metode penelitian yang digunakan dalam penelitian ini adalah studi kepustakaan. hasil dan kesimpulan dari penelitian ini yakni strategi komunikasi kesehatan dalam membangun partisipasi publik dimasa pandemi covid-19 adalah 1) kampanye komunikasi kesehatan harus dilakukan secara terintegrasi dan berkesinambungan serta dilakukan oleh para ahli, 2) menciptakan dan menerapkan strategi komunikasi yang tepat dan efektif dalam penanganan Covid-19, 3) menyusun taktik dan teknis tindakan dan prosedural yang tepat, efektif serta efisien.
\end{abstract}

Kata Kunci: Strategi komunikasi; Komunikasi kesehatan; Partisipasi public; Pandemi covid-19.

doi: https://doi.org/10.51544/jlmk.v5i1.2036

(C) 2021 Jurnal Lensa Mutiara Komunikasi. This is an open access article under the CC BY-SA license Website: http://e-journal.sari-mutiara.ac.id/index.php/JLMI/

http://e-journal.sari-mutiara.ac.id 


\section{PENDAHULUAN}

Pada hakikatnya pembangunan kesehatan adalah suatu usaha yang dilakukan oleh seluruh komponen bangsa dengan tujuan untuk meningkatkan kesadaran dan kemampuan, dan keinginan untuk hidup sehat. Selain itu pembangunan kesehatan juga betujuan sebagai investasi pembangunan SDM yang produktif baik secara sosial maupun ekonomi. Tolok ukur kebehasilan pembangunan kesehatan ditentukan dari keterkaitan antar program dan sektor serta bersinambungannya upaya yang telah dilakukan oleh Pemerintah yang telah menjabat pada periode-periode sebelumnya (Britnell, 2015).

Saat ini kondisi dunia tengah dilanda pandemi, yakni pandemi covid-19. Covid-19 telah diidentifikasi sebagai penyakit pernapasan yang menular (Kannan, Shaik Syed Ali, Sheeza, \& Hemalatha, 2020). Per 12 Juli 2021 terdapat 186.762.453 kasus di seluruh dunia sedangkan di Indonesia sendiri terdapat 2.563.400 kasus yang terkonfirmasi (Google News, 2021).

Adanya pandemi covid-19 yang dirasa cukup tiba-tiba menyebabkan kebingungan dari semua sektor, salah satunya adalah sektor kesehatan. Sektor kesehatan di Indonesia terlihat belum siap dengan adanya pandemi ini dalam mengkomunikasikan virus Covid-19 kepada masyarakat. Oleh karena itu, komunikasi kesehatan yang merupakan bagian dari komunikasi massal menjadi salah satu model komunikasi yang dapat menjembatani kepada masyarakat luas tentang kesehatan (Rodiah, Budiono, \& Rohman, 2018). Komunikasi kesehatan dibutuhkan guna mengetahui model penanganan kesehatan masyarakat juga sebagai acuan untuk melakukan tindakan lanjut di masa pandemi ini.

Knapp \& Vangelisti (2000: 420) dalam (Putra, 2016) mengemukakan bahwa seorang komunikator harus memiliki empat faktor penting, yaitu pengetahuan, pengalaman, motivasi dan sikap. Hal tersebut menunjukkan, saat berkomunikasi hendaknya komunikator memahami siapa lawan bicaranya dan sebagai apa dirinya saat itu. Selain itu seorang komunikator harus mampu berbicara seuai dengan pengetahuan, kemampuan serta memiliki sikap dan motivasi yang baik sesuai dengan pesan yang akan disampaikan, seseorang tidak boleh asal bicara, sehingga tidak memberikan informasi yang salah kepada orang lain, apalagi untuk permasalahan-permasalahan yang berkaitan dengan kepentingan umum yang berdampak besar bagi kehidupan banyak orang. Dalam hal ini, komunikator kesehatan adalah para tenaga medis yang meliputi dokter spesialis, dokter umum, apoteker, petugas laboratorium, ahli gizi, dan perawat (Nurgiwiati, 2017).

Wabah penyakit Covid-19 menyebabkan adanya krisis kesehatan global dan berdampak pada cara manusia dalam memahami kehidupan sehari-hari (Hasöksüz, Kiliç, \& Saraç, 2020). Pemerintah Republik Indonesia telah berupaya untuk melakukan langkah-langkah pencegahan dalam menangani pandemi covid-19. Beberapa langkah tersebut adalah sosialisasi tentang physical distancing, social distancing, Stay at Home, gerakan 3M, sampai larangan untuk mudik lebaran (Kemenkes, 2020).

Risiko penularan virus Covid-19 bisa diminimalisir dengan adanya strategi komunikasi para tenaga medis. Strategi komunikasi yang dilakukan tenaga medis sangat dibutuhkan dalam menangani pasien yang datang ke Rumah Sakit (RS) maupun Puskesmas. Pasien yang memiliki gejala serupa dengan Covid-19 sering mengalami kekhawatiran maupun ketakutan saat datang ke rumah sakit. Sehingga dalam hal ini pasien enggan terbuka kepada dokter dalam proses anamnesis di masa pandemi (Husain, 2020). Anamnesis adalah proses eksplorasi informasi tentang keluhan riwayat penyakit pasien. Proses anamnesis yang tepat dapat memudahkan dokter dalam mendiagnosis pasien sehingga dapat memberikan tindakan yang tepat (Zhang et al., 2011).

Berdasarkan penelitian yang dilakukan oleh Husain (2020) terdapat beberapa kejadian dimana pasien tidak terbuka dalam proses anamnesis di RS X, sehingga pasien tersebut 
menularkan virus Covid-19 pada tenaga medis yang tengah bertugas. Hal tersebut menyebabkan diagnosa dokter yang kurang tepat dan pasien tidak dapat ditangani dengan baik. Dalam bertugas, para tenaga medis harus memiliki strategi agar pasien dapat membuka diri dengan memberikan informasi keluhan yang dialami di masa pandemi saat ini.

Pada penelitian yang dilakukan oleh Kurniawan (2019) ditemukan bahwa berkat proses anamnesis, dokter dapat mengetahui pasien yang menderita penyakit cephalgia. Penyakit cephalgia adalah penyakit sakit kepala yang kerap dialami oleh masyarakat, penyakit ini mampu dideteksi sebab proses anamnesis. Dari proses anamnesis dapat diketahui tentang pola makan, pola tidur, hingga tingkat kecemasan yang dialami pasien. Anamnesis atau biasa disebut wawancara medis harus dapat memperoleh informasi yang tepat sebelum tahap diagnosa dan pemberian tindakan lanjut ke pasien sebab dalam hal ini penyakit cephalgia merupakan penyakit yang disebabkan oleh dehidrasi, stress, hipotensi, dan anemia. Selain itu, Setyorini (2019) dalam penelitian menemukan bahwa komunikasi interpersonal yang efektif yakni dengan menggunakan pendekatan bahasa juga pendekatan psikologis. Hal ini dilakukan dengan tahap pra pemeriksaan, pemeriksaan, tahap informasi awal (anamnesis), dan tahap penyampaian informasi.

Berdasarkan beberapa penelitian terdahulu, terlihat bahwa untuk mendapatkan informasi pada wawancara medis atau anamnesis maka dibutuhkan komunikasi yang efektid antara dokter dengan pasien. Sehingga peneliti tertarik untuk melakukan penelitian mengenai strategi komunikasi kesehatan dalam upaya membangun partisipasi publik yang berkesinambungan dalam pandemi covid-19.

\section{TINJAUAN LITERATUR}

\section{Komunikasi Kesehatan}

Banyak dari penyakit yang diderita oleh individu bermula dari ketidaktahuan atau kesalahpahaman dari berbagai informasi kesehatan yang diakses (Goldenberg, 2016). Dari hal tersebut perlunya memperhatikan dan menyaring informasi kesehatan yang diperoleh. Komunikasi kesehatan merupakan proses penyampaian pesan dari komunikator terhadap komunikan di bidang kesehatan baik dalam kehidupan sehari-hari maupun saat proses pelayanan (Notoatmodjo, 2010).

Adanya komunikasi kesehatan dapat membantu meningkatnya status kesehatan masyarakat jika dilakukan dengan komprehensif dan bekerja sama dengan instansi terkait (Nur R, Setyowati, \& Rosemary, 2020). Tujuan dari komunikasi kesehatan yakni adanya perubahan perilaku masyarakat menjadi lebih baik dalam meningkatkan kesehatan (Alfarizi, 2019).

Komunikasi kesehatan adalah cabang ilmu yang multidisipliner dengan menggunakan metode komunikasi massa (Notoatmodjo, 2012)(RISETDIKTI, 2016). Dampak dari komunikasi kesehatan adalah meningkatnya permintaan terhadap produk atau layanan kesehatan, mudahnya mengakses layanan kesehatan dan pemahaman masyarakat terhadap kesehatan modern (A \& Chalifah, 2020).

\section{Fungsi Komunikasi Kesehatan}

Komunikasi kesehatan merupakan sebuah cara yang dipakai untuk menyalurkan informasi, mempengaruhi seta memotivasi individu bahkan institusi di bidang kesehatan (Thomas, 2006). Komunikasi kesehatan memiliki tujuan supaya individu maupun masyarakat memahami informasi penting tentang kesehatan juga mengubah perilaku mereka supaya sesuai dengan asas-asas kesehatan (Notoatmodjo, 2010). 
Isu utama dalam komunikasi kesehatan yakni mempengaruhi individu juga komunitas. Hal itu bertujuan untuk meningkatkan derajat kesehatan dengan berbagi informasi tentang kesehatan. Centers for Disease Control and Prevention memaparkan bahwa komunikasi kesehatan merupakan studi tentang pengaplikasian strategi komunikasi untuk memberikan informasi dan mempengaruhi keputusan individu maupun kelompok dalam peningkatan derajat kesehatan (Schiavo, 2014).

\section{Peran Komunikasi Kesehatan}

Komunikasi kesehatan berperan dalam meningkatkan kesadaran individu tentang masalah kesehatan, masalah kesehatan, risiko kesehatan dan solusi kesehatan. Intinya adalah bahwa peran komunikasi kesehatan adalah untuk memberikan pemahaman kepada individu dalam masyarakat tentang perilaku sehat. Oleh karena itu, perlu dilakukan perubahan perilaku agar komunikasi kesehatan dapat menjadikan individu lebih sehat (Muchsin, 2009).

Komunikasi kesehatan mengacu pada interaksi antara kesehatan dan perilaku individu. Individu berada dalam situasi biologis, psikologis dan sosial (Notoatmodjo, 2010). Ketiga faktor tersebut mempengaruhi kesehatan seseorang. Melalui komunikasi kesehatan, kita mempelajari pertukaran antara ketiga faktor ini. Pemahaman ini penting agar kedepannya dapat dikembangkan intervensi program kesehatan yang bertujuan untuk mengubah perilaku individu ke arah yang lebih sehat.

Ketika digunakan dengan benar, komunikasi kesehatan dapat mempengaruhi sikap, persepsi, kesadaran, pengetahuan, dan norma-norma sosial, yang semuanya berfungsi sebagai pendahulu perubahan perilaku (Notoatmodjo, 2010). Komunikasi kesehatan sangat efektif dalam mempengaruhi perilaku, karena mengembangkan dan mengkomunikasikan pesan untuk promosi dan pencegahan kesehatan berdasarkan psikologi sosial, pendidikan kesehatan, komunikasi massa dan pemasaran.

\section{METODE PENELITAN}

Metode penelitian yang digunakan pada penelitian ini adalah studi literatur (library research), yaitu melalui pengumpulan data serta informasi dengan bantuan materi, seperti buku, dokumen, majalah dan sebagainya (Sari \& Asmendri, 2018). Studi kepustakaan dapat dilakukan pula dengan mempelajari referensi-referensi dari buku serta hasil penelitian sejenis yang telah dilakukan sebelumnya yang bermanfaat untuk dijadikan landasan teori terkait permasalahan yang hendak diteliti. Prosedur penelitian yang dilakukan melalui beberapa langkah, seperti: memilih topik, mengeksplorasi informasi, penentuan fokus penelitian, mengumpulkan sumber data, penyajian data serta menyusun laporan. Kemudian dilakukan analisis data berupa Content Analysis, untuk memperoleh kesimpulan valid dan konteksnya dapat diteliti ulang (Krispendoff, 1993). Langkah analisis data dilakukan dengan proses pemilihan, membandingkan, penggabungan dan pemilihan berbagai istilah atau pengertian hingga diperoleh pengertian yang sesuai dengan topik yang diteliti (Danandjaja, 2014).

\section{HASIL DAN PEMBAHASAN}

\section{Strategi Komunikasi Kesehatan di Indonesia dalam penanganan Covid-19}

Komunikasi kesehatan adalah upaya sistematis yang berdampak positif pada praktik kesehatan populasi besar. Tujuan utama komunikasi kesehatan adalah untuk mencapai peningkatan kesehatan dalam kaitannya dengan praktik dan status kegiatan. Meskipun banyak profesional di lapangan membuat perbedaan dalam hal istilah pendidikan kesehatan; komunikasi 
kesehatan; Promosi kesehatan; dan informasi, pendidikan dan komunikasi (Information, Education and Communication).

Strategi pada hakikatnya adalah suatu rencana (planning) dan kepemimpinan (management) untuk mencapai suatu tujuan (Effendy, 2003). Menurut (Littlemore, 2003) strategi komunikasi adalah langkah-langkah yang harus dilakukan untuk meningkatkan efektivitas komunikasi. Sedangkan strategi komunikasi menurut (Effendy, 2003) merupakan kombinasi dari perencanaan komunikasi (communication planning) dan manajemen komunikasi (communication management) dalam rangka mencapai suatu tujuan. Untuk mencapai tujuan tersebut, strategi komunikasi harus dapat menunjukkan bagaimana operasi taktisnya harus dilakukan, dalam arti pendekatan (approach) dapat berbeda setiap saat tergantung pada situasi dan kondisi.

Jadi kesimpulannya adalah bahwa strategi komunikasi kesehatan merupakan perpaduan antara perencanaan dan manajemen komunikasi yang dilakukan oleh organisasi untuk mencapai tujuan bersama. Tujuan dari strategi komunikasi yang dilaksanakan adalah untuk mengelola dan mengatasi masalah kesehatan, yaitu yang berkaitan dengan krisis penyebaran virus corona atau Covid-19.

Berdasarkan konsep strategi komunikasi yang dijelaskan oleh Harold D. Laswell (2007), dikutip oleh (Effendy, 2003), untuk memahami strategi komunikasi seseorang harus dapat menjawab pertanyaan-pertanyaan berikut: Siapa komunikator, pesan apa dia mengatakan, media apa yang digunakan, siapa komunikatornya, dan efek apa yang diharapkan. Dan mereka semua adalah elemen komunikasi. Oleh karena itu, berikut ini adalah strategi komunikasi kesehatan yang dapat dilakukan dalam menghadapi Covid-19 di Indonesia, yaitu:

\section{Komunikator dalam Komunikasi Kesehatan Penanganan Covid-19}

R. Wayne Pace, Brent D. Peterson dan M. Dallas Burnet menyatakan dalam bukunya Techniques for Effective Communication, yang dikutip oleh (Effendy, 2003) bahwa tujuan utama kegiatan komunikasi terdiri dari tiga tujuan utama, yaitu: untuk memastikan pemahaman, untuk mengakui penerimaan menstabilkan dan memotivasi untuk bertindak.

Faktor pertama adalah "memastikan pemahaman" untuk memastikan bahwa komunikator memahami pesan yang diterima. Jika ia mampu memahami dan menerima, maka si penerima harus didorong "agar terjalin penerimaan". Pada akhirnya, aktivitas tersebut dimotivasi untuk "memotivasi untuk bertindak." Dengan demikian, orang yang menyampaikan pesan, yaitu komunikator, menentukan keberhasilan komunikasi.

Kredibilitas sumber komunikator memegang peranan yang sangat penting. Istilah kredibilitas adalah istilah yang menunjukkan nilai bawaan dari keahlian dan kepercayaan. Seorang komunikator memilih kredibilitas berdasarkan etosnya yaitu apa yang dikatakan Aristoteles dan yang selama ini dijadikan pedoman adalah akal sehat, akhlak yang baik dan akhlak yang baik, kemudian akan dapat dipercaya oleh para sarjana modern yang dirumuskan dalam niat baik (good intentions), layak untuk dipercaya (Trustworthiness) dan kompetensi atau keahlian (Effendy, 2004).

Komunikator memegang peranan penting dalam komunikasi. Seorang komunikator harus memiliki faktor penting dalam memulai komunikasi, faktor pertama adalah sumber daya tarik, seorang komunikator akan berhasil dalam berkomunikasi, ia akan mampu menyampaikan sikap, pendapat dan perilaku komunikan melalui mekanisme Perubahan daya tarik. ketika komunikan merasa bahwa komunikator berpartisipasi dengannya. Dengan kata lain, komunikator merasakan 
adanya kemiripan antara komunikator dengan dirinya sendiri sehingga ia siap untuk mematuhi isi pesan yang dikirimkan oleh komunikator (Effendy, 2003).

Faktor kedua adalah sumber kepercayaan, kepercayaan komunikator terhadap komunikator merupakan salah satu faktor yang dapat mengantarkan pada keberhasilan komunikasi. Keyakinan ini sangat berkaitan dengan profesi atau keahlian seorang komunikator. Seorang dokter akan mendapatkan kepercayaan diri ketika dia menjelaskan tentang kesehatan (Effendy, 2003).

Karena kedua faktor tersebut, seorang komunikator harus berempati dalam berhubungan dengan komunikan. Dengan kata lain, seorang komunikator bisa merasakan apa yang dirasakan oleh komunikan. Seorang komunikator perlu berempati ketika berkomunikasi dengan komunikan yang sibuk, marah, bingung, sedih, sakit, kecewa, dan lain-lain (Effendy, 2003). Intinya, dalam strategi komunikasi kesehatan menghadapi Covid-19, pemerintah harus memilih komunikator yang tepat. Jika berdasarkan penjelasan di atas, kriteria yang dapat dipilih untuk menentukan komunikator kesehatan dalam menghadapi Covid-19 adalah berakal sehat, memiliki akhlak yang baik, dapat dipercaya, serta memiliki kompetensi atau keahlian.

\section{Komunikan dalam Upaya Pencegahan Penyebaran Covid-19}

Komunikan adalah yang menjadi target sasaran komunikasi, pihak yang menjadi penerima pesan dalam sebuah komunikasi yang sekaligus adalah tujuan komunikasi. Dalam penyampaian informasi kesehatan, terdapat komunikan utama, yang perilakunya diharapkan dapat dipengaruhi melalui komunikasi kesehatan. Terkadang penerima manfaat kesehatan tidak mampu bertindak untuk diri mereka sendiri, misalnya, bayi dan anak kecil atau orang dengan cacat mental. Dalam hal itu, komunikan utamanya adalah orang-orang yang membuat keputusan bagi mereka. Selain komunikan utama, komunikasi kesehatan juga dapat ditujukan untuk komunikan sekunder dan tersier untuk mempengaruhi komunikan primer. Komunikan sekunder dan tersier dapat mencakup anggota keluarga atau teman yang memiliki pengaruh pada komunikan utama (Parvanta \& Bass, 2020). Dikarenakan COVID-19 ini dapat menjangkit kepada siapa saja tanpa melihat kondisi demografis seseorang, maka semua lapisan masyarakat menjadi komunikan primer dalam upaya komunikasi kesehatan dalam upaya melawan COVID19.

\section{Pesan dalam Komunikasi Kesehatan di masa pandemi Covid-19}

Pesan dalam Strategi Komunikasi Kesehatan Penanganan Covid-19 ini sangat jelas, yaitu pesan kesehatan untuk menghindari penyebaran atau penularan virus corona atau Covid-19. Maka pesan-pesan yang disusun adalah bagaimana seorang komunikator memberikan pesanpesan tentang apa yang ahrus dilakukan maupun yang dilarang untuk mencegah atau terhindar dari virus ini. seperti cuci tangan pakai, masker, jaga jarak dan tidak boleh berkerumun.

Pesan merupakan segala hal yang disampaikan dari komunikator kepada penerima (Sastropoetro, 1987). Pesan tersebut harus mengandung pesan dasar (topik) yang mempengaruhi upaya pelanggan untuk mengubah sikap dan perilaku. Pesan dapat disampaikan dalam jangka waktu yang lama, tetapi tujuan akhir dari hubungan tersebut perlu ditangani.

Pesan komunikasi memiliki tujuan tertentu. Ini mendefinisikan teknik yang akan diperoleh, apakah itu teknik informasi, teknik persuasi, atau teknik instruksional. Sebuah pesan komunikasi terdiri dari isi dan simbol pesan. Isi pesan komunikasi mungkin sama, tetapi simbol yang digunakan dapat berbeda. Simbol meliputi bahasa, bentuk, gerak tubuh, warna, dan sebagainya. Simbol yang paling banyak digunakan dalam komunikasi adalah bahasa, karena 
hanya bahasa yang dapat mengungkapkan pikiran, perasaan, fakta, pendapat, hal-hal yang nyata dan abstrak, pengalaman masa lalu, tindakan masa depan, dan sebagainya. Oleh karena itu, bahasa memegang peranan yang sangat penting dalam komunikasi. Tanpa kemampuan berbahasa, sebaik apapun proses berpikir, tidak akan mungkin dapat berkomunikasi dengan baik dengan orang lain. (Effendy, 2003).

Dalam komunikasi kesehatan penanganan Covid-19 ini, tujuan utamanya adalah bagaimana pesan tersebut tepat sasaran sehingga mampu difahami dan dimengerti oleh masyarakat Indonesia serta pada akhirnya mampu mengubah sikap dan perilaku masyarakat agar hidup sehat terhindar dari virus ini. Suryanto (2015) menjelaskan supaya pesan yang disampaikan tepat sasaran, maka harus sesuai dengan kriteria-kriteria yakni:

a. Pesan harus disiapkan dengan baik

b. Pesan dapat dipahami oleh semua pihak

c. Pesan mampu menarik perhatian

Selanjutnya, pesan harus informatif, kredibel, dan menarik. Pesan yang bersifat informatif, seperti memberikan informasi tentang fakta dan data, kemudian pelanggan membuat kesimpulan dan keputusannya sendiri. Persuasi adalah pesan yang dimaksudkan untuk memberi kesan kepada seseorang bahwa apa yang disampaikan akan mengubah sikap penerima pesan, dan perubahan itu diterima melalui kesadaran dan keterbukaan, bukan melalui paksaan. Coercion adalah pesan yang bersifat memaksa dan menggunakan sanksi. Pemaksaan berupa perintah atau instruksi untuk menyampaikan target (Suryanto, 2015).

\section{Media yang digunakan dalam Komunikasi Kesehatan masa pandemi covid-19}

Pemilihan media komunikasi kesehatan dalam penanganan Covid-19 merupakan hal yang sangat penting, media berkaitan dengan bagaimana pesan kesehatan tentang penanganan Covid19 ini dapat mencapai sasaran dan diterima serta dipahami oleh masyarakat Indonesia. Terlebih negara kita memiliki wilayah yang luas, maka pertu pertumbangan matang untuk memilih media apa yang tepat yang dapat digunakan. Disesuaikan pula dengan pola perilaku, sikap dan budaya tiap daerah.

Sebagai contoh didaerah perkotaan yang masyarakatnya cenderung melek akan media sosial, maka pemiliha media sosial sebagai medium komunikasi dapat dipertimbangkan, namun bagi masyarakat yang berusia lanjut hal tersbut belum tentu tepat, maka melalui media konvensional dapat menjadi pilihan.

Dalam pemilihan media, dapat memilih satu bahkan memilih gabungan dari beberapa. Tergantung tujuan, penyampaian pesan dan teknik yang digunakan. Kalau kita bicara media mana yang bagus, jawabannya tidak pasti, karena masing-masing media memiliki kelebihan dan kekurangannya masing-masing.

Bisa menggunakan media cetak, media elektronik, maupun media internet atau media sosial. Bisa pula media berbentuk visual, audio, atau audiovisual (iklan), bisa gambar, foto, video, media luar ruangan seperti spanduk, baligho, poster, banner maupun bentuk lainnya. Contoh pesan yang dikirim melalui media tulis/cetak dan media visual memiliki keunggulan karena dapat dicek ulang dan disimpan sebagai dokumen. Selain itu, pesan media audio digunakan untuk melakukan hal lain, seperti mendengarkan radio saat mengemudi atau mengemudi. Anda dapat melihat dan mendengarkan berbagai pesan media audio-visual (Effendy, 2003). 
Maka dari itu dalam memilih media komunikasi kesehatan penanganan Covid-19 ini harus memperhatikan hal-hal tersebut diatas, sepeti tujuan yang ingin dicapai, target sasaran, serta mempertimbangkan kelebihan dan kekurangan dari media yang akan digunakan.

\section{KESIMPULAN}

Strategi komunikasi kesehatan dalam penanganan Covid-19 dibuat bertujuan Mempengaruhi keputusan, sikap dan perilaku individu dan kelompok yang bertujuan untuk memberikan informasi dan meningkatkan kesadaran publik Indonesia untuk dapat mengikuti berperilaku hidup sehat mengikuti protokol kesehatan untuk menghindari keramaiaan atau kerumunan demi terhindar dari penyebaran virus Covid-19.

Strategi komunikasi merupakan langkah penting untuk meningkatkan efektivitas komunikasi. Dalam hal ini, maka diperlukan sebuah strategi komunikasi kesehatan berupa perencanaan komunikasi kesehatan dan manajemen kesehatan yang tepat dan efektif agar penanganan Covid-19 dapar berjalan baik, efektif dan berhasil. Keberhasilan ini tentunya akan berjalan lancar ketika seluruh lapisan masyarakat dapat bersinergi dalam upaya hidup sehat.

Adapun Strategi komunikasi kesehatan dalam penanganan Covid-19 dapat dilakukan melalui hal berikut, yaitu:

1. Kampanye Komunikasi kesehatan harus dilakukan secara terintegrasi dan berkesinambungan tentang bagaimana cara Mencegah Penularan Virus Corona atau Covid-19 sebagai tindakan pencegahan selanjutnya memberikan panduan mengenai langkah-langkah yang perlu dilakukan untuk menanggulangi atau mengobati jika terkena virus-19. Dengan melibatkan tim ahli kesehatan atau medis dalam rangka menyusunnya.

2. Menciptakan dan menerapkan strategi komunikasi yang tepat dan efektif dalam penanganan Covid-19, salah satunya dengan memperhatikan unsur-unsur komunikasi agar komunikasi yang dijalankan efektif dan tepat sasaran, seperti: memilih dan memilah komunikator sebagai sumber pesan yang tepat; pemilihan dan penggunaan pesan yang efektif; memilih media komunikasi yang efektif dan tepat sasaran; memahami komunikan yang menjadi sasaran komunikasi kesehatan yakni masyarakat Indonesia, misalnya dengan dengan memperhatikan kultur, psikologis, kerangka pemikiran (frame of reference) dan bidang pengalaman (field of experience) serta keunikan lainnya, karena rakyat Indonesia terkenal dengan keragamannya belum lagi faktor demografis dan geografis, hal-hal tersebut mutlak harus menjadi pertimbangan; serta efek yang diharapkan yaitu perubahan sikap dan perilaku masyarakat dalam mencegah penularan covid-19.

3. Untuk melakukan dan mengimplementasikan strategi komunikasi kesehatan dalam rangka penanganan covid-19, selanjutnya harus dapat menurunkannya kepada tataran taktik dan teknis tindakan dan prosedural yang tepat, efektif dan efisien pula

\section{DAFTAR PUSTAKA}

A, P. A., \& Chalifah, R. R. (2020). Komunikasi Kesehatan dan Penanganan Covid 19 di Kalangan Keluarga. Jurnal Kesehatan.

Alfarizi, M. (2019). Komunikasi Efektif Interprofesi Kesehatan Sebagai Upaya Peningkatan Kualitas Pelayanan Rumah Sakit. ETTISAL: Journal of Communication.

Britnell, M. (2015). In Search of the Perfect Health System. In Search of the Perfect Health System. 
Danandjaja, J. (2014). Metode Penelitian Kepustakaan. Antropologi Indonesia.

Effendy, O. U. (2003). Ilmu, Teori dan Filsafat Komunikasi. Citra Aditya.

Effendy, O. U. (2004). Ilmu Komunikasi Teori dan Praktek. Bandung: Rosdakarya.

Goldenberg, M. J. (2016). Public misunderstanding of science? Reframing the problem of vaccine hesitancy. Perspectives on Science.

Google News. (2021). Virus corona (COVID-19) - Google Berita. Retrieved July 16, 2021, from https://news.google.com/covid19/map?hl=id\&mid=\%2Fm\%2F03ryn\&gl=ID\&ceid=ID\%3A id

Hasöksüz, M., Kiliç, S., \& Saraç, F. (2020). Coronaviruses and sars-cov-2. Turkish Journal of Medical Sciences.

Husain, A. H. Al. (2020). Komunikasi Kesehatan Dokter dan Pasien Berbasis Kearifan Lokal Sipakatau di Masa Pandemi. Jurnal Ilmu Komunikasi.

Kannan, S., Shaik Syed Ali, P., Sheeza, A., \& Hemalatha, K. (2020). COVID-19 (Novel Coronavirus 2019) - recent trends. European Review for Medical and Pharmacological Sciences.

Kemenkes. (2020). Pedoman kesiapan menghadapi COVID-19. Pedoman kesiapan menghadapi COVID-19.

Krispendoff, K. (1993). Analisis Isi Pengantar Teori dan Metodologi. Yogyakarta Penerbit Kanisius.

Kurniawan, B. C. (2019). Peran Anamnesis Terhadap Kesembuhan Pasien Cephalgia. INA-Rxiv. Retrieved July 16, 2021, from https://osf.io/preprints/inarxiv/4btdh/

Littlemore, J. (2003). The communicative effectiveness of different types of communication strategy. System, 31(3), 331-347. Pergamon.

Muchsin, A. (2009). Perlindungan Hukum Terhadap Pasien Sebagai Konsumen Jasa Pelayanan Kesehatan Dalam Transaksi Terapeutik. Jurnal Hukum Islam (JHI).

Notoatmodjo, S. (2010). Komunikasi Kesehatan. Promosi Kesehatan Teori Dan Aplikasi.

Notoatmodjo, S. (2012). Promosi Kesehatan dan Perilaku Kesehatan. Journal of Chemical Information and Modeling.

Nur R, T. H., Setyowati, H. N., \& Rosemary, R. (2020). Rumah Gizi 'Aisyiyah: Komunikasi Kesehatan dengan Pendekatan Agama-Budaya. Jurnal Komunikasi Global.

Nurgiwiati. (2017). KOMUNIKASI KESEHATAN DALAM PENANGANAN PASIEN PADA INSTALASI GAWAT DARURAT RUMAH SAKIT UMUM DR. H. YULIDIN AWAY KABUPATEN ACEH SELATAN. Efektifitas Pijat Refleksi Dan Pijat Tubuh Terhadap Asam Urat Darah Dan Skala Nyeri Pada Pasien Hiperurisemia Di Ciledug.

Parvanta, C. F., \& Bass, S. B. (2020). Health communication: strategies and skills for a new era. 
Healt communication: strategies and skills for new era.

Putra, N. (2016). Karakteristik Komunikator Yang Efektif Dalam Komunikasi Antar Pribadi. Jurnal Komunikasi Islam dan Kehumasan ....

RISETDIKTI. (2016). Kebijakan Pendidikan Jarak Jauh dan E-Learning di Indonesia. Jurnal Kesehatan.

Rodiah, S., Budiono, A., \& Rohman, A. S. (2018). Model Diseminasi Informasi Komunikasi Kesehatan Masyarakat Pedesaan di Kabupaten Bandung Barat. Jurnal Kajian Komunikasi, 6(2), 175-190. Universitas Padjadjaran. Retrieved July 16, 2021, from https://journal.unpad.ac.id/jkk/article/view/17771

Sari, M., \& Asmendri. (2018). Metode Penelitian Kepustakaan (Library Research). Penelitian Kepustakaan (Library Research) dalam Penelitian Pendidikan IPA.

Sastropoetro, S. (1987). Pendapat Publik, Pendapat Umum, dan Pendapat Khalayak dalam Komunikasi Sosial. Bandung: Remaja Rosdakarya.

Schiavo, R. (2014). Strategic health communication in urban settings: A template for training modules. Strategic Urban Health Communication.

Setyorini, I. (2019). Efektifitas Komunikasi Dokter Dalam Membangun Kepercayaan Pasien (Studi Kasus Komunikasi Interpersonal Dokter Dan Pasien Di Klinik Nirmala Husada).

Suryanto. (2015). Pengantar Ilmu Komunikasi. Bandung: CV Pustaka Setia.

Thomas, R. K. (2006). Health communication. Health Communication.

Zhang, Z., Ahmed, F., Ramakrishnan, A. M. I. V, Zhao, R., Viccellio, A., \& Mueller, K. (2011). AnamneVis: a framework for the visualization of patient history and medical diagnostics chains. IEEE VAHC Workshop. 